\title{
Morphological Characteristics and Phylogenetic Relationship of Pineapple [Ananas comosus (L.) Merr.] in Several District in Tapanuli Utara Regency
}

\author{
Ester Nadia Panjaitan ${ }^{1}$, Diana Sofia Hanafiah ${ }^{2}$ Rosmayati $^{3}$ \\ \{esterpanbers4@gmail.com ${ }^{1 *}$, dedek.hanafiah@yahoo.co.id ${ }^{2}$, tanjungrosmayati@yahoo.co.id ${ }^{3}$ \} \\ 1,2,3 Agroecotechnology Departemen, Universitas Sumatera Utara, Indonesia \\ *esterpanbers4@gmail.com
}

\begin{abstract}
One of the pineapple cultivation areas in Sumatera Utara is Tapanuli Utara. Pineapple is a tropical fruit that can high economic value if it has good fruit quality. Pineapple fruit development needs to done related to the demands of the market. One way to obtain superior varieties is through exploration and selection. The research aims to identify the qualitative characteristic and phylogenetic relationship of pineapple in several districts of Tapanuli Utara Regency, North Sumatra. This research uses survey method based on UPOV (International Union for the Protection of New Varieties of Plants) based on dissimilarity matrix. This research showed that accession of pineapple in Tapanuli Utara still have a far level relationship. The nearest phylogenetic relationship is AN2 and AN3 with coefficient Euclidean 1.773 and farthest phylogenetic relationship is AN26 and AN9 with coefficient Euclidean 71.773 based on the difference qualitative characteristics.
\end{abstract}

Keywords: pineapple, morphological characteristic, phylogenic relationship, Tapanuli Utara Regency.

\section{Introduction}

Pineapple [Ananas comosus (L.) Merr] is a very important fruit plant because besides being consumed in fresh form, pineapple can be processed into various kinds of products. Pineapple also contains all the vitamins and minerals in small amounts that can be useful for health. But the potential for pineapple is not optimal both in terms of quality and quantity [1].

Indonesia is the third country that producer pineapple in the world. In 2016 national pineapple production reached 1.396 .153 tons while in 2017 pineapple production reached 1.795.986 tons. Pineapple production in 2017 increased by 399.833 tons, while pineapple production in North Sumatra Province reached 160.552 tons $(8.94 \%)$ which is the second largest pineapple producer after Lampung province which reached 633.095 tons (35.25\%) [2]

The potential of Indonesian pineapple fruit is quite good but it has not yet been pursued optimally because of the high level of competition with other horticultural products, still low quality and quantity of local pineapple supply and price information and market information is still not transparently to the farmer level. In general, some characteristics inherent in the development of pineapple are the unplanned development. The farmers know the price information based on previous seasons, while the balance of the amount of supply and demand can still not well anticipated [3].

Plant breeding activities need to be done to increase the potential of pineapple. One of the plant breeding activities is exploration or characterization activities, which are identifying 
important traits that are of economic value or which are the characteristics that the relevant genotype. Plant characterization activities are one of the methods used to see the characteristics of plants, both qualitative and quantitative characters [4]

In 2015 Tapanuli Utara Regency had a pineapple plant area of 1,927.80 ha with a total production is $34,477.57$ tons. The area which is the center of pineapple plants in North Tapanuli Regency is in Sipahutar District. The aims of characterization activities to local pineapple in the district of North Tapanuli is as a source of germ plasm to support of plant breeding programs [5]

\section{Materials and Methods}

This research was conducted in Tapanuli Utara Regency, namely in Sipahutar District, Pangaribuan District, and Garoga District. The study starts from May to August 2019. The material used in this research was 27 accessions of pineapples in three districts in North Tapanuli District including is Sipahutar District, Pangaribuan District and Garoga District. The tool used in this research is camera, GPS, ruler, labels, questionnaire form and stationery.

The method used in this study is a survey method that is to identification characteristics of pineapple plants in several districts in Tapanuli Utara Regency. Sampling was taken in 3 districts in Tapanuli Utara regency, then choose 3 villages were randomly selected in each of the districts, in each villages take 3 samples were taken randomly (accidental sampling) to obtain 27 accessions of pineapples. Each plant is given the symbol AN (Aksesi Nenas). Pineapple accessions were taken at Sipahutar District (AN1-AN9), Pangaribuan District (AN10-AN18) and Garoga District (AN18-AN27). Observations data was carried out through the morphological characteristics of pineapple plants both qualitative and quantitative based on UPOV (International Union For the Protection of New Varieties Of Plants) [6] namely immature fruit color, fruit shape, fruit dominant color, evenness of color of eyes, color of flesh, size of fruit eye, flesh density, flesh fibrousness, flesh aroma, flesh juiciness dan flesh sweetness.

Data of qualitative characteristics then analyzed using phylogenic relationship using the IBM SPSS (Statistical Program for Social Science) with euclidie distance cluster analysis as follows.

$$
d i, j=\sqrt{\sum_{k=1}^{p}\left(x_{i k}-x_{j k}\right)^{2}}
$$

With:

$d i, j=$ the distance between object $i$ and objek $k$

$x_{i k}=$ value of object $i$ on variable to $k$

$x_{j k}=$ value of object $j$ on variable to $k$

$p=$ number of cluster variables

[7]. 


\section{Results and Discussion}

Based on observations from 3 districts namely Sipahutar district, Pangaribuan district and Garoga district qualitative characteristics were obtained for each accession. Observation of the morphological characteristics of immature fruit color there are 4 variations namely gray found in AN10, dark green found in AN6, AN11, AN12, AN13, AN15, AN16, AN17, AN18, AN18, AN21 and AN25, purple are found in AN8, AN9, AN19, AN22, AN23 and AN24 and light green are found in the other accessions.

Observations on the fruit shape there are 4 variations, namely fruit shape of narrow ovate found on AN4, AN8, AN9, AN16, AN18, AN21, AN22, AN23, AN24 and AN25, fruit shape of medium ovate found on AN3, AN7, AN10, AN14, AN15, AN20, AN26 and AN27, fruit shape of circular found in AN17, and fruit shape of elliptic fruit is found in AN1, AN2, AN5, AN6, AN11, AN12, AN13, and AN19.

Observations of fruit dominant color there are 7 variations, namely the fruit dominant color of yellow green found in AN14, AN15, AN20, and AN26, fruit dominant color of green found in AN4, AN5, AN6, AN8, and AN17, fruit dominant color of grey green found in AN10, AN11, AN12, AN13, AN16, AN18, AN19, AN22, AN23 and AN25, fruit dominant color of light yellow found in AN7, fruit dominant color of medium yellow found in AN1, AN2, AN3, AN21, and AN27, fruit dominant color of orange found in AN9, fruit dominant color of red is in AN24. Observations for evenness of color of eyes there are 2 variations, namely uniform of eye color is even or slightly uneven found in AN1, AN2, AN3, AN4, AN5, AN6, AN7, AN8, and AN9. And other accessions uniform of eye color is slightly uneven.

Observations of morphological characteristic of flesh include color of flesh, flesh density, flesh fibrousness, flesh aroma, flesh juiciness and flesh sweetness. In observing of flesh color evenness there is only 1 variation, even or slightly uneven that found in 27 identified pineapple accessions. flesh density parameters there are 3 variations namely flesh density of dense found in AN1, AN14, AN21, AN24 and AN27, flesh density of medium found in AN2, AN3, AN4, AN5, AN13, AN15, AN17, AN19, AN20, AN23 and AN26 and flesh density of loose found in other accessions. In the flesh fibrousness parameters there are 2 variations namely medium fruit fibrousness found in AN19 and AN20 and other accessions have low fruit fibrousness.

Observation of the parameters of flesh aroma there are 3 variations, namely the strong flesh aroma found in AN1, the medium flesh aroma found in AN2, AN3, AN4, AN5, AN6, AN10, AN11, AN13, AN14, AN20, AN21 and AN27 and other accession is the weak flesh aroma. In the flesh juiciness parameters there are 3 variations, namely high flesh juiciness in AN1, AN13, AN14 and AN27, low flesh juiciness in AN9, AN16, AN17, AN18, AN19, AN22, AN23, AN24, AN25 and other accessions have moderate flesh juiciness. In the parameters of flesh sweetness there are 3 variations namely low flesh sweetness found in AN12, AN16, AN19, AN20, AN22, AN23, AN24, and AN25, medium flesh sweetness found in AN9, AN10, AN11, AN14, AN15, AN18, AN21, and AN26, and other accessions have high flesh sweetness 


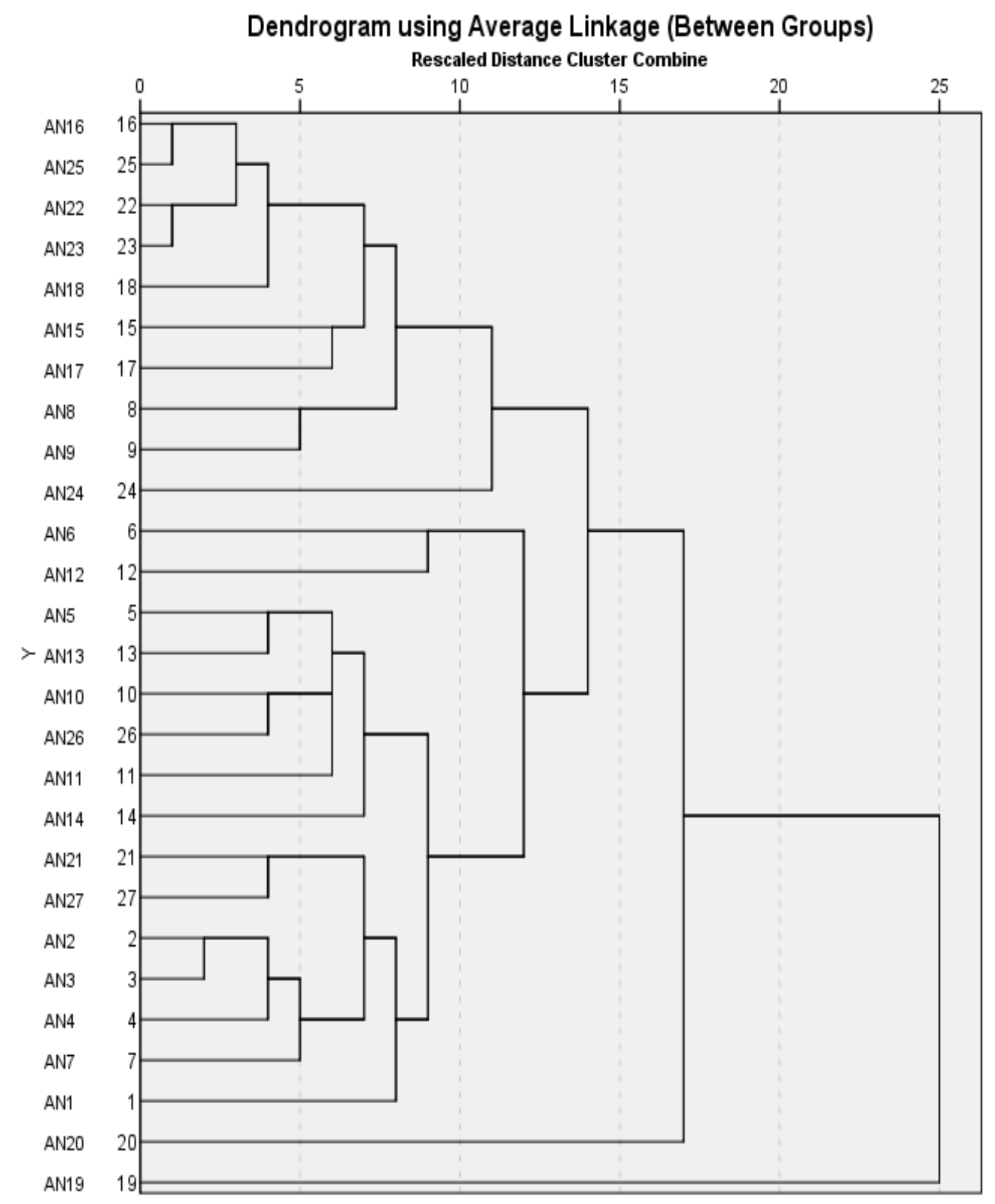

Fig 1. Dendogram of several pineapple accessions 


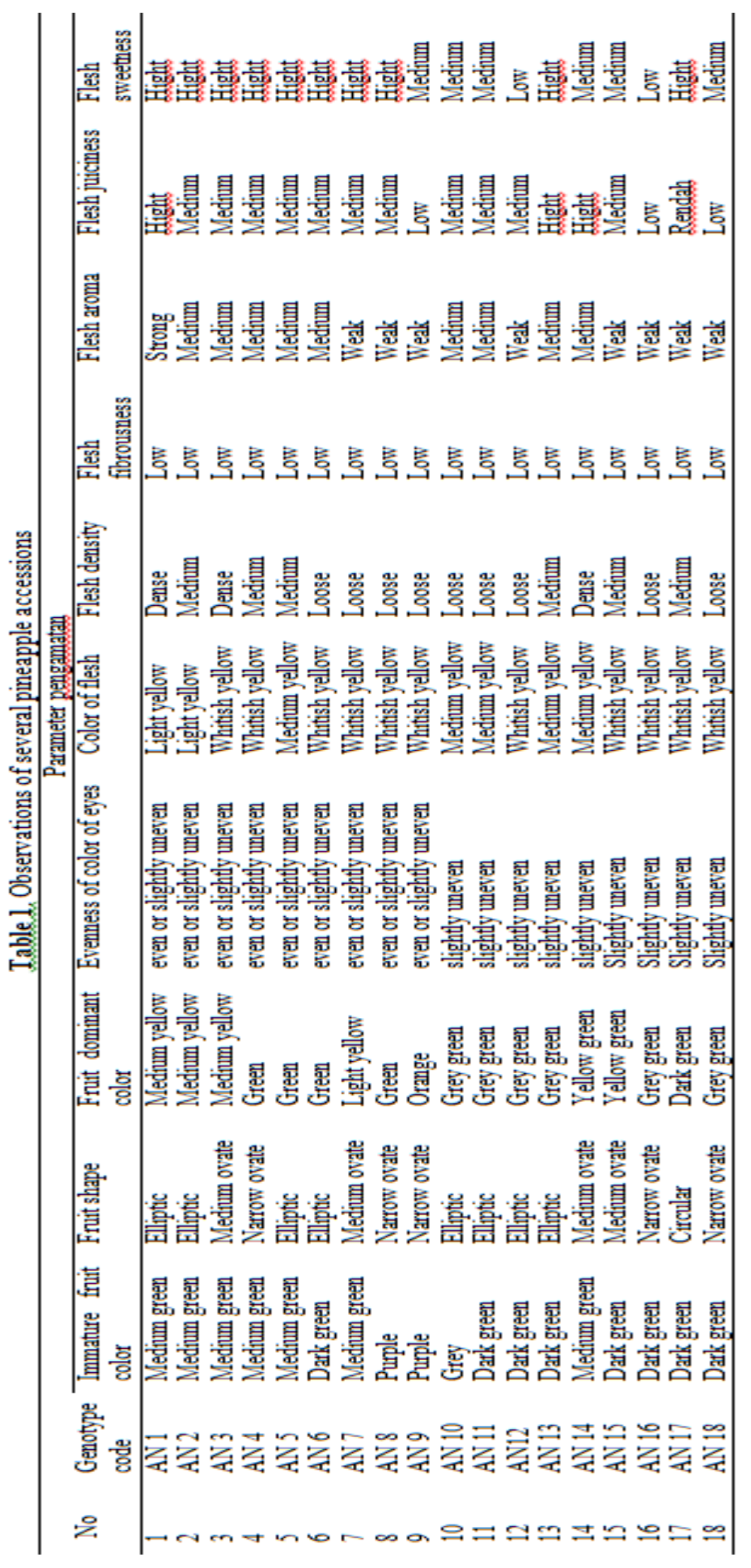




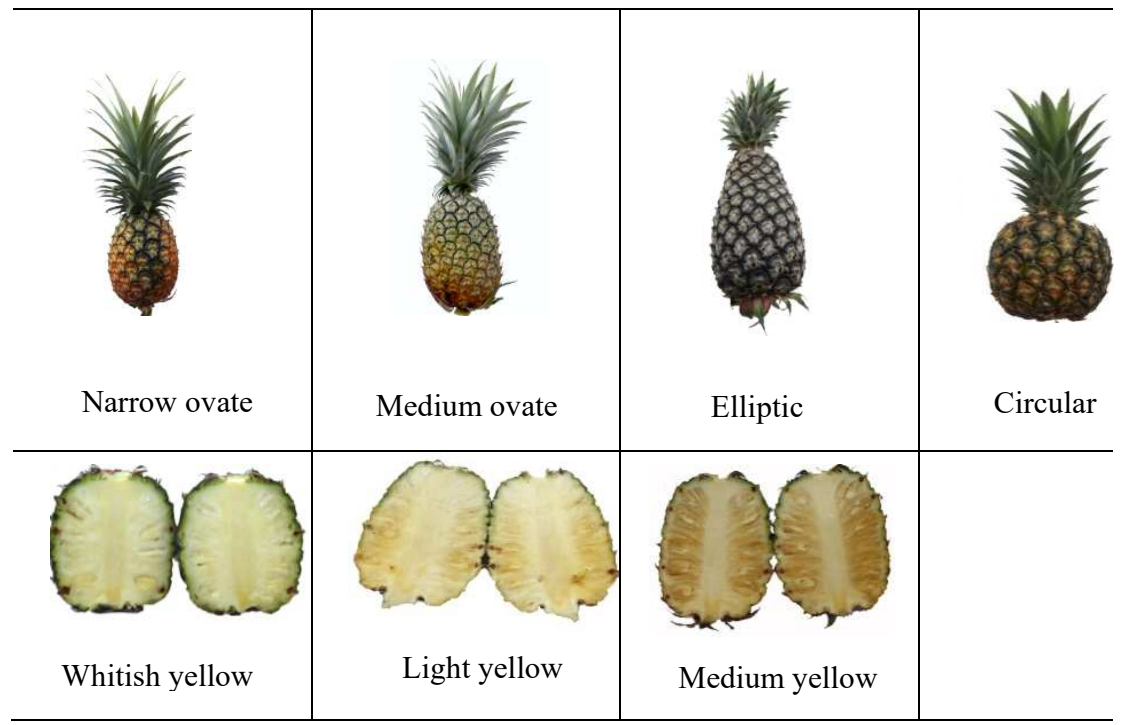

Fig 2. Differences of Morphological characteristic of fruit shape and color

The problem of pineapple development in Tapanuli Utara Regency is the problem of cultivation techniques and the still not development superior varieties seen from interviews with the farmers. The interview results obtained that in cultivation techniques in general farmers do not fertilize of pineapple plants, both chemical fertilizers and organic fertilizers. Farmers also still use local varieties of pineapple seedlings from each region. Pineapple seedlings that are widely used are seedlings from pineapple plants, both of slips, aerial suckers on stem, and from fruit crowns. Pineapple development in Indonesia has not received serious attention as reflected in fluctuating harvested area and productivity [8]. This is caused by various things including is still not development of superior varieties and cultivation techniques have not been optimal.

The results of this research are generally different. The average level of flesh sweetness in Sipahutar district is high, in Pangaribuan district the flesh sweetness is medium or sweet, but Garoga district have the average level of flesh sweetness is low. Morphological characteristics maybe influenced of factors environment. Diversity in phenotypic appearance is represented by qualitative and quantitative characters. Required by many genes or environmental factors in each accession [9]

The lowest coefficient euclidean or the nearest phylogenic relationship AN2 and AN3 obtained from Sipahutar district is 1.773 only has 1 qualitative character difference from 12 related qualitative characters, namely the fruit shape character. Morphological characters can determine differences and similarities in the appearance of morphology of external species that can be used to find distant kinship relationships [10].

The highest coefficient value or the farthest phylogenic relationship AN26 obtained from Garoga District and AN9 obtained from Sipahutar District is 71.773 with 7 different characters from 12 characters displayed such as immature fruit color, fruit shape, color of flesh, evenness of color of eyes, fruit dominant color, flesh density and flesh juiciness. This shows that the level of morphological similarity in the 27 identified pineapple accessions is 
far. The similarity distance is far if it is less than 0.6 or $60 \%$. So from the grouping it can be said that twenty-seven accessions of pineapple that observed have a high or large phylogenic relationship [11].

\section{Conclusion}

The results of pineapple exploration conducted in North Tapanuli Regency are Sipahutar District (accession 1-9), Pangaribuan District (accession 10-18) and Garoga District (accession 19-27). The results of Morphological characterization for fruit shape (narrow ovate, medium ovate, Elliptic, and circular) and fruit flesh (whitish yellow, medium yellow, light yellow). The nearest phylogenic relationship AN2 and AN3 with a dissimilarity matrix of 1.773 while the farthest phylogenic relationship AN26 and AN9 with a dissimilarity matrix of 71.773 based on qualitative characters.

\section{Acknowledgments}

Thanks to the farmers in Sipahutar District, Pangaribuan District, and Garoga District of Tapanuli Utara Regency who have contributed in providing information for this research.

\section{References}

[1] Hadiati S, Ni L P. Pineapple cultivation. Tropical Fruit Plant Research Institute. Solok (2008).

[2] Central Bureau of Statistics Republic of Indonesia (BPSRI). Statistics of Annual Fruit and Vegetable Plants. Central Bureau of Statistics of Indonesia. Jakarta. (2017).

[3] Lubis, RRB., Daryanto, A., Tambunan, M., Rachman, HPS. Technical Efficiency Analysis of Pineapple Production: Case Study in Subang Regency, West Java. Journal of Agro Economic. (2014).

[4] Swasti, E.A. Syarif, I. Suliansyah, N. E. Putri. Exploration, Identification and Utilization of Rice Germ plasm from West Sumatra. Research Report basic Research Intensive Program in 2007. Andalas university research institute. (2007).

[5] Central Bureau of Statistics. Agriculture Statistics of Tapanuli Utara Regency. Central Statistics Agency of Tapanuli Utara Regency. Tarutung. (2015).

[6] UPOV (Union for the Protection of New Varieties of Plants). Guidelines for the conduct of tests for distinctness, uniformity and stability - Pineapple (Ananas comosus (L.) Merr). (2013).

[7] Mongi, M. Plant genetic diversity in Makmur, A (Ed.) Introduction to Plant Breeding. Directorate General of Higher Education Ministry of National Education. Jakarta. (2001).

[8] Surahman, M., Santosa, E., Nisya, F.N. Characterization and Analysis of Jatropha Germplasm Groups in Indonesia and Several Other Countries Using Morphological and Molecular Markers. Indonesian Agronomy Journal. (2009). 
[9] Hanafiah, D. S., Sanggita, S., Lubis, K. The phenotypic appearance of Japanese persimmon (Diospyros kaki L.F.) in Karo District, North Sumatera, Indonesia. Biodiversitas. (2018).

[10] Suskendriyati, H., A. Wijayati., N. Hidayah., D. Cahyuningdari. Morphological and Relationship Study of Pondoh Salak (Salacca zalacca (Gaert.) Voss.) Varieties in the Sleman Highlands. UNS, Surakarta. (2000).

[11] Cahyarini, R.D., Ahmad Y, Edi P. Identification of Genetic Diversity of Some Soybean Local Varieties in Java Based on Isozyme Analysis. Agrosciences. (2004). 